\title{
Irrigation and territory in the southeast of Spain: evolution and future perspectives within new hydrological planning
}

\author{
A. L. Grindlay ${ }^{1}$, C. Lizárraga ${ }^{2}$, M. I. Rodríguez ${ }^{1} \&$ E. Molero ${ }^{1}$ \\ ${ }^{I}$ Department of Urban and Regional Planning, \\ University of Granada, Spain \\ ${ }^{2}$ Department of Applied Economics, University of Granada, Spain
}

\begin{abstract}
The model of the regional economic development of southern Spain cannot be understood without taking into account intensive irrigated agriculture and its inextricable relationship with water availability. In this semi-arid territory, the need to ensure the efficiency of agricultural water use has been a constant, which has led to the gradual modernization of systems of resource use. However, the total water demand in the Segura River Basin and Almeria province has increased to exceed the limits of natural resources, resulting in a structural water deficit with an unsustainable trend, as is highlighted in hydrological planning.

In this paper we analyse the shape, socio-economic and environmental consequences of the expansion of irrigation in Murcia and of greenhouses in Almeria. It becomes clear that the main shortcoming is the structural shortage of groundwater. The paper concludes with the idea that, despite this severe limitation, more productive irrigation could absorb the higher costs of a solution based on water from coastal desalination to solve the hydrological deficit and, in turn, can become a guarantor of the quality of the ecosystems, food security and good territorial order within the sector.

Keywords: irrigation, water, regional economic development, new hydrological planning, Almeria, Murcia.
\end{abstract}

\section{Introduction}

The defining feature of the south-eastern peninsular of Spain, where the provinces of Almeria Murcia are located, respectively in the Andalusian 
Mediterranean Basin and the Segura River Basin, is aridity. This is manifested by extraordinary solar radiation and scarce and irregular rainfall - both periodic and geographic, although of a torrential character in autumn. These climatic conditions, initially adverse for development [1], have turned the region into a very productive and profitable area for irrigated agriculture, though with the limitation of meagre available water resources, which was resolved with the early construction and development of hydraulic works [2].

The regional development model has been highly dependent on water, both in regards to the agricultural sector and the coastal urban, residential, tourist and metropolitan areas. Agricultural development took place founded on the traditional ancient irrigated areas of the alluvial plains and experienced a significant expansion from the second half of the twentieth century in the case of Murcia [3], and in the large expansion of greenhouses from the end of the 1960s in the case of Almeria [4]. The evolution of these processes of expansion shows a tendency towards a steep logistical curve with a slight gradual increase at the beginning, followed by a stage of rapid development and intense growth between the mid-1980s and the end of the 1990s, until it reached a stage of maturity at the beginning of the new century, when growth became significantly reduced. This stabilization in the tendency for growth reveals, on the one hand, a slowing down in the processes of expansion linked in recent times to the grave scarcity of resources and, on the other hand, the later development has been balanced with the loss of productive land by urbanization [5]. In the case of Almeria it has almost reached a limit in occupation, as a result of the creation of a seemingly "plastic sea" of greenhouses which has become one of the most outstanding territorial transformations in recent decades on a global scale $[4,6]$.

In general, irrigation is inextricably linked to the availability of water. Without doubt, both the growth of irrigation in the region of Murcia and the spectacular proliferation of greenhouses in Almeria has moved away from the traditional Mediterranean irrigation culture adapted to its particular conditions of scarcity and has been supported, since the 1970s, by the use of subterranean resources which have accumulated in the subsoil. In Almeria this began with the governmental action of colonization, and also in the successful application in the 1970s of a number of technical innovations ("sanding" - creation of an artificial ground, plastic greenhouses - which contribute to the growth in productivity, to early harvest and savings in water consumption, etc.) which has led to an extraordinary economic development classified as a miraculous $[2,4]$, and has resulted in an agricultural revolution [7].

The Water Framework Directive (WFD) approved in the European Union, and adopted as the Spanish standard (through Laws 62/2003 and 11/2005), in addition to the good ecological state of the bodies of water, requires a new criteria of economic rationality in water management. Each economic area is obligated to provide analysis of the degree of fulfilment with regards to the recovery costs for water services, in order to increase efficiency and equity in their use. The economic analysis should include a long-term forecast of supply and demand and, where data are unavailable, estimates of the volume, price and cost associated with water services. The price of the water should be included in 
the program of measures, so that it is considered as another measure and is analysed in terms of cost and effectiveness [8].

Currently in the Segura River Basin, where the region of Murcia is situated, some $87 \%$ of the water goes to irrigated agriculture [9], and in the Andalusian Mediterranean Basin this percentage is a lower, but equally significant, $71 \%$ [10].

The inseparable relationship between water and irrigated land in regions where the scarcity of water is a characteristic feature, has forced a gradual modernization in the systems of irrigation, by means of regulation or re-use and rationing of water, and has led to its productivity becoming the highest in Spain. In much of the Spanish territory, access to water resources is the determining factor explaining the economic and financial viability of agricultural operations, their physical productivity, profitability and rural land values [11]. However, the development of the sector clashes with environmental limitations and the new parameters of economic rationality established in the WFD.

This paper analyses the importance of irrigated agriculture in the territory and economy of the provinces of Almeria and Murcia, the efforts to improve its operation and the challenges faced by a fragile but very competitive sector. To this end, Section 2 shows the evolution of irrigated land and its socio-economic and territorial implications. Section 3 discusses the productivity and modernization of irrigated lands. Section 4 analyses the perspectives and challenges for the future.

\section{Irrigation as a dynamic catalyst in the agricultural sector in the economy and its territorial implications}

In general, throughout the second half of the twentieth century, the economy of the region of Murcia has mirrored the cycles of the Spanish economy. The changes happening in the economy of Murcia in the period 1971-1987 include a spectacular growth in the capital stock of hydraulic infrastructures - with the works for the Tajo-Segura Transfer and other expansions and development, a prolonged and profound crisis, followed by a period of recovery coinciding with the incorporation of Spain into the European Union [12]. The infrastructural development which took place from the mid-1960s until the mid-1980s, coincided with the expansion of irrigated areas and the accelerated process of urbanization which took place in the region.

Amongst the Spanish regions, Murcia has a per capita income below the national average. During the 1960s there was a dramatic increase in absolute and relative terms. After this period of strong growth, Gross Added Value (GAV) per capita had not exceeded $85 \%$ of the national average and since 2005 one sees a loss of position in the per capita production of the region.

Between 1955 and 1975, the increase in per capita income was accompanied by a structural change characterized by the progressive loss of importance of the agricultural sector in its contribution to global production. During the "hard" period of autarkic and interventionist economic policy, the isolation of the country had negative consequences for irrigated specialized agriculture and the agro-food industry, the most dynamic sectors of the economy of Murcia [13]. 
The processes of modernization and specialization, which could already be felt in the nineteenth century, were interrupted, and a ruralisation of society was experienced. The population employed in the agricultural sector rose from $49 \%$ in 1930 to $60.5 \%$ in 1950 [12]. Although the reduction in relative importance of the agricultural and fisheries sector paralleled the national productivity structure, it is necessary to take into account two adjacent aspects of the model of structural change which from a quantitative perspective moved agriculture into a lesser position. Firstly, there was a rural exodus which took place from predominantly agricultural regions to the more industrialized regions in the $1950 \mathrm{~s}$ and $60 \mathrm{~s}$, a situation which had an impact on the modernization of the techniques of agricultural production and, therefore, on the productivity of the sector. Secondly, after the crisis of the mid-1970s, the decreased capacity of the sector to employ workers led to an increase in rural unemployment and in unskilled workers, unqualified and difficult to place in other sectors.

The spectacular economic development of Almeria, linked to the generalization of intensive agriculture, leads to what is widely known as the "Almerian miracle" [4]. From the beginning of the 1970s the growth of the economy of the province of Almeria has been higher than the national average [14] and, in terms of GNP per capita, Almeria elevated its place in the Spanish ranking from the lowest position, which it occupied in the 1960s to stand now in an intermediate position on a national level and first amongst the Andalusian provinces, having gained more than 30 percentage points [4].

In Murcia since 1995, the contribution of the agricultural sector to the Gross Domestic Product (GDP) and to employment has continued to decrease, whilst maintaining regional agricultural specialization. For its part, the greatest contribution to the Final Agricultural Production in 2004 was the agricultural subsector, with $76.4 \%$, followed by livestock farming. The productivity rate for the agricultural sector in the Region of Murcia is above the Spanish average, due to irrigated agriculture. In fact, the survival of some agricultural operations was based on their transformation into irrigated land with higher margins than those of unirrigated land which, only in exceptional cases, gives a profit of over 900 Euros/hectare. Irrigated land has a gross margin per hectare of 4.4 times that of irrigated land, and is the basis for the production of the highest economic value (90\% of horticultural and citrus crops, $75 \%$ of tubers, between $20 \%$ and $30 \%$ of vineyards, olive, fodder and industrial crops). The same species growing in an irrigated greenhouse reaches yields of up to eight times greater than that of unirrigated farming. Irrigation in Murcia is linked to a dynamic and competitive agricultural model and, without state aid to production, reaches net margins of more than 7,000 Euros/hectare. Such differences are based on the diversification of production, in the minimisation of climatic risk and the growing techniques used. In addition, irrigated land generates up to fifty times more direct employment than un-irrigated land on the Mediterranean coast and the ties between agriculture and non-agricultural businesses in the region generate 35\% more employment over and above agriculture itself. In addition, there is a strong relationship between irrigated land and the agricultural food industry. The high agricultural productivity of the region explains the formation of complexes of agricultural food production of high 
importance, which places Murcia as a leader in conserved vegetable industries and in pre-prepared fruit and vegetable products. In some municipalities the weighting of the agricultural food industry in local production is six times greater than that of the average in the Spanish economy.

In Murcia since 1995, the contribution of the agricultural sector to the Gross Domestic Product (GDP) and to employment has continued to decrease, whilst maintaining regional agricultural specialization. For its part, the greatest contribution to the Final Agricultural Production in 2004 was the agricultural subsector, with $76.4 \%$, followed by livestock farming [15]. The productivity rate for the agricultural sector in the Region of Murcia is above the Spanish average, due to irrigated agriculture. In fact, the survival of some agricultural operations was based on their transformation into irrigated land with higher margins than those of un-irrigated land which, only in exceptional cases, gives a profit of over 900 Euros/hectare. Irrigated land has a gross margin per hectare of 4.4 times that of irrigated land, and is the basis for the production of the highest economic value $(90 \%$ of horticultural and citrus crops, $75 \%$ of tubers, between $20 \%$ and $30 \%$ of vineyards, olive, fodder and industrial crops). The same species growing in an irrigated greenhouse reaches yields of up to eight times greater than that of un-irrigated farming [16]. Irrigation in Murcia is linked to a dynamic and competitive agricultural model and, without state aid to production, reaches net margins of more than 7,000 Euros/hectare [11]. Such differences are based on the diversification of production, in the minimisation of climatic risk and the growing techniques used. In addition, irrigated land generates up to fifty times more direct employment than un-irrigated land on the Mediterranean coast and the ties between agriculture and non-agricultural businesses in the region generate $35 \%$ more employment over and above agriculture itself [12, 17]. In addition, there is a strong relationship between irrigated land and the agricultural food industry. The high agricultural productivity of the region explains the formation of complexes of agricultural food production of high importance, which places Murcia as a leader in conserved vegetable industries and in preprepared fruit and vegetable products. In some municipalities the weighting of the agricultural food industry in local production is six times greater than that of the average in the Spanish economy [11].

In the middle of the current decade the agricultural GAV represents $11 \%$ of the total GAV of Murcia and more than $23 \%$ of the GAV of the province of Almeria. Horticulture represents $52 \%$ of the final agricultural production of Murcia and $83 \%$ of that of Almeria, and fruit and vegetable produced in both provinces make up almost half the national production [18].

In addition the growth of the indigenous and, in particular, the immigrant population in recent decades is associated with this productivity and level of agricultural employment, whereby the work is often undertaken by illegal immigrants. In fact, the strong demand for labour caused by the expansion of horticultural production in Almeria, with its agriculture under industrialised plastic and in Murcia -both intensive in capital and manual labour- have been met to a large extent by illegal immigration, which has balanced the decrease in indigenous workers in the sector [18]. 
The modernization of the agricultural sector in Murcia and Almeria is closely linked to the opening of export. The balance of trade, in deficit until the 1990s, took an upturn thanks, primarily, to the strong expansion of horticulture. The agricultural balance of trade went from a payment rate of $82 \%$ in 1985 to $110 \%$ in 1999 and exports of final agricultural production rose from $30 \%$ to $56 \%$ in the same period. Furthermore, exports of food products made up $70 \%$ of total exports in the 1990s [19]. The payment ratio (export/import) of the agricultural food sector is very much higher than that of the total commercial payment ratio. In fact, since 2000, the region of Murcia demonstrates a commercial deficit, whilst the agricultural food sector maintains its surplus, even though this worsens its competitive international position [13]. In Almeria the percentage of the horticultural produce destined for export has stopped being lower than the $30 \%$ at the end of the $1980 \mathrm{~s}$, to be $60 \%$ in 2003 , and both provinces, Murcia and Almeria, create more than half the national horticultural produce, with $26 \%$ and $35 \%$ respectively [18].

Irrigated land offers higher profitability than other forms of agriculture and has played a key role in the modernization of the agricultural sector. Despite the difficulties facing the country, the transformation began in Murcia in the 1940s with the policy of reserves, continued in the 1950s with its progressive modernization and increase in productivity and in the 1960s diversified production to meet the new demands for food. With the development of motorization for the extraction of groundwater, the irrigated areas were extended beyond the alluvial flood plains, in a continuous process, giving rise to a serious over-exploitation of aquifers. The huge increase in gross irrigated areas experienced in the $1950 \mathrm{~s}$ and $60 \mathrm{~s}$ is associated with the construction of large hydraulic works in the basin which provided a very elevated regulation (around $80 \%$ of the natural flow) [2]. Public and private investments made to improve the system of regulation and increase the availability of water were justified by their positive impact on regional economic growth. The improvements and modernization of irrigation systems enabled the attainment of higher levels of profitability and increased export capacity of a capitalized and intensive agriculture. In the 1970s there was a significant increase in the surface area of irrigated land, not only as a result of state action (post-transfer irrigated areas), but also the private initiative turned to the extraction of groundwater. Water demand from the new irrigated areas which were created with the supply from the transfer adversely affected the traditional water deficit of the region, despite that it was met, in part, with subterranean resources [3]. In the case of coastal Almeria, a series of technical innovations, instigated initially by state action and rigorously followed up by private initiative, such as, from the 1950s, the extraction of groundwater, the introduction of greenhouses in 1963 or the generalisation of drip irrigation in 1976, led to an extraordinary growth in horticultural production, which has more than quadrupled between 1975 and 2008 , rising from some 670,000 tons to more than $2,900,000$ tons [4], but has also led to a significant over-exploitation and degradation of its aquifers [7, 10].

The net irrigated surface of Murcia maintained a certain superficial stability over the general regulatory process in the 1970 s, being in the region of 100,000 
hectares. Later, in the 1980s there was a period of development and strong expansion associated with the transfer. In the 1990s the net irrigated surface stabilized again, with the limited resources of the transfer for irrigation and the shortages caused by the droughts in the middle of this decade [2]. The works of the Tajo-Segura transfer and post-transfer (since 1979) allowed an increase in the surface area of irrigated land, which rose from 166,689 hectares in 1984 to 221,085 hectares in 1991. Such an increase signified a huge stimulus for traditional agriculture, which was subject to profound changes in cultivation techniques and in types of crop. The changes in techniques meant an increase in intensive farming and "drip" irrigation. In 2004 the irrigated land surface reached its maximum, due to the high availability of resources, coinciding with the registered extension of 251,121 hectares [9].

The various studies carried out up to now in the Segura River Basin demonstrate a variable evolution of the net irrigated area for the period 19802005 in terms of water availability and which has not surpassed the figure established in the last hydrological plan [9]. The difficult outlooks for agriculture, together with the recent economic dynamics clearly oriented towards construction, have led to the urbanization of these areas. The area occupied by greenhouses in Almeria has grown spectacularly from their start in the mid1960 s, and the scarcely 4,000 hectares in the mid-1960s has become 30,000 hectares [20], becoming the Spanish province with the most surface area of greenhouse cultivation, representing about half the national surface area, and very much higher than the rest of the countries of the Mediterranean basin [4]. These widespread expansions explain their relevance in the territorial configurations of Murcia and Almeria.

However, the expansion of the irrigated areas has brought with it, in general, serious environmental impacts, which include direct changes in natural habitats, over-exploitation of water resources, salinization and pollution (localised and diffuse) [21]. In particular, in the Segura River Basin, the most significant pressures on the surface water bodies, linked to the development of irrigated areas, include extraction of resources in water systems; hydro-morphological changes, regulation of the water system; pressures for the use of land, specific and diffuse pollution. In addition, the bodies of groundwater have been overexploited, which has caused seawater intrusion and diffuse contamination. Almost $10 \%$ of the surface bodies of water have been evaluated as at risk of not meeting the environmental objectives of the WFD [9]. On the other hand, the rapid and wide-spread expansion of greenhouses in Almeria has produced serious environmental problems, like the worsening of the water deficit and the over-exploitation and salinization of the aquifers, the production of vegetable waste, of plastics from greenhouses, packaging from weed killers and pesticides, and the general pollution of water and ground by the use of fertilizers, and pesticides. This is in the process of being resolved through large advances in waste management and the response to pollution through integrated production [22]. It is anticipated that the coastal aquifers of Almeria will reach a healthy state in 2027, doing away with over-exploitation and pollution, with the extension of the "Campo de Dalias" which would justify less rigorous 
environmental objectives [10]. According to the facts uncovered, the recovery of the hydrological environment is going to be linked to the improvement in the efficiency (technical, productive and economic) in the use of water for agriculture $[11,17]$ and in the adequate territorial organization of its land $[4,20]$.

The scarcity, lack of guarantee and low water quality constitute the main structural weakness and limitation of the irrigated land, as presented in the forecasted scenarios of current hydrological planning in the Segura River Basin and the Andalusian Mediterranean Basin. Despite these limitations, and as will be demonstrated later, the most productive irrigated land could carry the costs of a solution based on water from coastal desalinization which constitutes a guaranteed and quality supply proposed by current hydrological planning to solve the water problems $[9,10]$.

\section{Water use, productivity and modernization of irrigated land}

The total demand for water in the Segura River Basin has increased over the years with a growing intensity, until it is exceeding the limits of the existing natural resources, leading to a structural water deficit with an unsustainable trend [23]. According to studies carried out for the compilation of the next Hydrological Plan, the total water demand for consumption has risen from $1,750 \mathrm{hm}^{3}$ per year to $1,901 \mathrm{hm}^{3}$ per year and, specifically, demand for agricultural uses, which made up $80 \%$ of the total, now stands at $87 \%$. In particular, the demand for water, linked to the expansion of irrigated areas, and established in the last Hydrological Plan as $1,660 \mathrm{hm}^{3}$ per year, has increased slightly to $1,662 \mathrm{hm}^{3}$ per year, due to the stabilization of this use [10].

At the beginning of the twenty-first century, the contribution of irrigated land to the final agricultural production is around $90 \%$, despite only occupying $13 \%$ of the useable agricultural area. The differences in productivity are greater for different types of crop. According to data on covered crops (horticulture, flowers and ornamental plants), these carry most added value per unit of water ( 7.83 Euros $\left./ \mathrm{m}^{3}\right)$, followed by vegetables $\left(2.09 \mathrm{Euros} / \mathrm{m}^{3}\right)$ and it is worth noting that the productivity of these crops in the Segura River Basin is higher than the national average [11]. Productivity of irrigation water has risen between 1996 and 2007 [24]. Fruit and vegetable production concentrated on the Mediterranean coast maintains a high profitability and productivity, despite the difficulties of supply and the depletion of available water in the local area [25].

Thus, the need for greater efficiency in agricultural water use has been a constant in the semi-arid Mediterranean territory, with irrigated areas traditionally in deficit with their scarce and irregular water allotments. In those territories of the Segura with greater difficulties obtaining this resource, or in its distribution, improvements and the new irrigation techniques began to spread, which constituted the first antecedents of the modernization of irrigation. During the 1960s, the reduction of losses was considered through the improvement of the distribution network, the incorporation of new subterranean resources and the use of floodwaters. Later, a new distribution system was established and its 
complete automation and computer control. In parallel, there was a wide-spread diffusion of localized irrigation, at the end of the 1970s, from the coast throughout the whole of the Basin [26].

Traditional water policy opted for the transfer of external flows to the Mediterranean basins to resolve the age-old water deficit. Its action paradigm, from a supply model, was the Tajo-Segura Transfer, and this approach was maintained by the provisions of the National Hydrological Plan of 2001, which included the Transfer from the Ebro River. The change in this water policy and its paradigms of management, produced with the modification of the above mentioned National Hydrological Plan and its substitution by the A.G.U.A. Program (Actuaciones para la Gestión y Utilización del Agua - "Actions for the Management and Utilization of Water") in 2004 (R.D.L. 2/2004) [27]. This contained a series of "Urgent Actions in the Mediterranean Basin" to increase water supplies through desalination and improvements in the management and quality of water seeking independence from climatic influence with the massive desalination of sea water [7].

Over recent years, and as has been established in the WFD, Hydrographical Demarcations have been established, which incorporate the confederations, and which are undertaking actions aimed at optimizing existing storage and distribution infrastructures, of irrigated land and urban water supply, with particular attention to purification and re-utilization, as well as, above all, desalination. According to the A.G.U.A. program, the actions of the Autonomous Community of the Region of Murcia will create an increase of $204 \mathrm{hm}^{3}$ per year (with an investment of 876 million Euros) and in Almeria of $189 \mathrm{hm}^{3}$ per year (with an estimated cost of 352 million Euros). The government chose desalination instead of large inter-basin transfers, exchanging a very tangible and immediate form of environmental impact for the less tangible environmental impact of additional energy production [7].

Since then it has continued with policies of savings and modernization of the irrigated areas, making agricultural activity a more efficient sector in the use of water. The modernization of irrigated areas was among the agricultural and environmental policies of the European Union, as well as of the state government, but finally converging in the Ministry of the Environment, Rural Marine Affairs, with the actions of the Emergency Plan for the Modernization of Irrigated Areas (R.D. 287/2006) to alleviate drought; the Law 45/2007 for Sustainable Rural Development and the current National Strategy for the Sustainable Modernization of Irrigated Areas, up to 2015.

\section{Prospects and challenges of irrigated areas}

European Agenda 2000 sees multifunctional irrigated areas as one of the pillars of the new model of European agriculture, as it settles the population, orders the territory and maintains the rural area [28]. In Consequence, the programs of improvement and modernization of irrigated areas and their future planning are framed in a context of territorial order broader than the purely hydraulic and 
incorporate parameters of sustainable development, settlement and employment of the population in rural areas.

More than two thirds of the total area of irrigated land in Murcia has been modernized, using sprinkler or localized irrigation systems, to the point where the Region has come to be considered "a laboratory of modernization experiments" which has been successful in terms of savings and efficiency in water use, its regulation, distribution and control. Murcia is the region with the highest percentage of land with drip irrigation (77.31\%), followed by the Canary Islands (73.94\%) and Andalusia (73.67\%) [29]. A significant part of this latter percentage corresponds to irrigation systems in the greenhouses of Almeria. However, the administration is obliged to guarantee water for irrigation so that the modernisation system works [26]. Nevertheless, the framework imposed by the WFD in Europe is leading to some significant limitations in the use of water to achieve the objectives of the good ecological state of the bodies of water and of the aquatic ecosystems, its subsequent maintenance and its sustainable use as a resource. To achieve these in 2015, the Hydrographical Demarcations are preparing new hydrological plans for the basin which should have been passed by 2009 .

The objectives established in the current hydrological plan proceed from the WFD (basically aimed at achieving the good state of all bodies of water and aquatic ecosystems and the sustainable use of water), as well as from the current Water Law which, besides supplementing the Directive, is already considering the adequate satisfaction of water demand for the various uses. Firstly, the environmental objectives are a top priority legal requirement for most water uses of the basin. The level of environmental degradation of a significant part of the aquatic ecosystems of the zones is serious limitations to the achievement of these objectives. Their achievement will lead to a restriction in the system of use, reducing the limited availability of water, mainly for irrigation, which will mean one of the greatest difficulties to face in the demarcations. For this reason, once the ecological flows and their annual and inter-annual systems are determined, a concerted process must be achieved, taking into account environmental conditions, socio-economic effects and the costs of the measures which are proposed during the next three cycles of planning (until the year 2027) for its implementation. The over-exploitation of aquifers is negatively affecting the ecosystems which rely on them and are leading to rising pumping costs for the users of an increasingly scarce resource Another of the objectives identified refers to the satisfaction of the demands and the rationality of use. However, particular attention is drawn to the limitations in the satisfaction of the demands of agricultural use due to the reduction in the quantity of water available in the basins $[9,10]$.

Current water planning intends to fulfil this shortfall with water from desalination. However, the resolution of this gap in water supply with the incorporation of desalinated water for the cycle of agricultural use will present greater difficulties than for urban or industrial uses. In order to take a decision on the best solution in the management of irrigation water, it is essential to determine a shadow price and take account of the socio-environmental costs, and 
consider the willingness of the irrigators to pay in order to guarantee the good state of the water ecosystems. Current water prices in the regions of the southeast are lower than their shadow price (between 0.06 and 0.21 Euros $/ \mathrm{m}^{3}$ ), causing an excess in demand which could be reduced with the increase in prices. From this perspective, measures such as desalination or water markets, combined with an increase in prices, in both water from surface sources as well as subterranean sources, could solve the water shortage. The use of water from desalination plants is economically feasible for greenhouse irrigation in the coastal areas to the south of the Campo de Cartagena and for Almeria's coastal areas. However, as the costs of extraction $\left(0.09-0.18\right.$ Euros $\left./ \mathrm{m}^{3}\right)$ are much lower than those of desalination $\left(0.52\right.$ Euros $\left./ \mathrm{m}^{3}\right)$ and as the hydraulic administration does not exert an effective control on the aquifers, it is difficult for the farmers to use desalinated water. Sustainable management of the aquifers would require public action and co-operation between interested parties in the zone [20,30].

The difficulty of the introduction of desalinated water in consumption cycle (both for urban and agriculture uses) for its high cost compared to groundwater is causing the underutilization of existing desalination plants in Almeria, which are functioning at a level well below its production capacity (between 16 and 33\%) and the review of the A.G.U.A. Program respect to non-construction or nonexpansion of programmed desalination plants [20]. Therefore, proposals for subsidized pricing to promote its acceptance among users should be considered as recommended [7].

Control of the over-exploitation of aquifers and springs is essential in order to achieve a sustainable use of the resource, but it requires a framework of open regulation to accommodate the local agents involved, and the commitment of the authorities concerned when necessary to limit the development of activities which endanger the objective of sustainability in the use of the basic resources. For this it is necessary to highlight the importance of social capital in irrigated areas, with its ancient model of collective management of water through the irrigation communities, which have become an international reference due to their efficiency and participative character [31].

In addition to the aspects considered, the development of an economic analysis is anticipated to include in the program of measures of the hydrological plan, in which the long-term supply and demand for water is forecast, to fulfil the criteria of cost recovery in the WFD and to increase efficiency and equality in resource use. However, in the current economic crisis, it is anticipated that the policy of modernization of irrigated areas and the huge investments necessary to implement the new hydrological plans and achieve the objectives of the WFD, is going to slow down [32].

Along with water related aspects, the future of the agricultural sector in the southeast depends on commitment to quality and innovation in activity, as key elements to maintain a competitive position through the differentiation of production and product identification with quality brands created for this purpose. The correction of deficiencies, like the strong differential between prices earned by the farmer and those paid by the consumer, forms part of the strategies aimed at strengthening the sector. In addition, co-ordination between 
agriculture and the agricultural food industry is a key aspect for Murcia to maintain its position in these sectors [33], innovations which in the case of Almeria have taken decades to bring about [4].

\section{Conclusions}

Irrigated land, as a dynamic element in agriculture, maintains an important role in the territorial configuration and economy of Almeria and Murcia, despite the loss of the relative importance of agriculture in production. Irrigated land has shown the highest rates of agricultural profitability and productivity and has played a key role in the modernization of the industrial sector.

In Murcia the large increase in gross irrigated area experienced in the 1950s and 60 s was related to the huge hydraulic works. In middle of the last decade the maximum irrigated area was reached, and more than two thirds of this has been modernized, incorporating sprinkler or localized irrigation systems, and has improved efficiency in water use in terms of its regulation, distribution and control. In Almeria the spectacular proliferations of greenhouses from the mid1960s, along with other technical innovations, such as localized irrigation, have been based on the use of groundwater, similar to that in Murcia. This has led to an increase in the traditional water deficit in both basins, and to serious environmental impacts, which include the over-exploitation of subterranean aquifers and the endangerment of the ecosystems which rely on them.

Scarcity, lack of guarantee, and low quality of the water constitute the main weakness and structural limitation of irrigated land, as presented in the future scenarios of current hydrological planning. One of the greatest difficulties in its implementation will be the process of agreement in which all the environmental, social and economic costs are to be considered, and the significant agricultural demands already existing in the basins can be addressed. Water from coastal desalination could be established as an economically feasible solution to meet the demands of the resource for its use in more productive irrigated agriculture. However the higher cost of desalinated water compared to subterranean extraction makes it difficult for irrigators to accept. For this reason, co-operation between interested parties in the area and public action to control overexploitation are essential to achieve change in the origin of water to meet the environmental objectives of the WFD.

The future of rural areas in general, and in particular of the irrigated land of Murcia and Almeria, requires special attention, beyond its mere consideration as a productive agricultural sector in many senses. International competition will quickly become stronger, due to the progressive liberalization of the sector on an international scale. A multi-sectorial base of development will be required founded on the diversification of activities and the re-evaluation of existing supplies in the rural environment. Moreover, the multifunctional role related to the satisfaction of the increasing demands of the public regarding safety and quality of food, product differentiation, animal welfare and environmental protection; converts rural inhabitants into guarantors of these increases in quality and of good territorial order. 


\section{Acknowledgements}

This work has been initially funded by the Spanish "Dirección General del Agua del Ministerio de Medio Ambiente" by a project untitled "Water, Engineering and Territory: The transformation of Segura river basin by hydraulic engineering". Also this work has been supported in part by the project P07-TIC-02913 Consejería de Innovación, Ciencia y Educación of the Autonomous Regional Government of Andalusia, untitled "Intelligent system for the environmental impact assessment of human activities (SINTEIA)".

\section{References}

[1] García, J., García-Latorre, J. \& Sanchez-Picón, A. Dealing with aridity: socio-economic structures and environmental changes in an arid Mediterranean region. Land Use Policy, 18, pp. 53-64, 2001.

[2] Gómez Ordóñez, J.L. \& Grindlay Moreno, A.L. (dirs.). Agua, Ingeniería y Territorio: La Transformación de la Cuenca del río Segura por la Ingeniería Hidráulica. Confederación Hidrográfica del Segura: Murcia,2008

[3] Morales Gil, A. Agua y territorio en la Región de Murcia. Fundación Centro de Estudios Históricos e Investigaciones Locales: Murcia, 2001.

[4] Aznar-Sánchez, J.A. \& Sánchez Picón, A. Innovación y distrito en torno a un "milagro": la configuración del sistema productivo local de la agricultura intensiva en Almería. Revista de Historia Industrial, 42, pp. 157-192, 2010.

[5] Grindlay, A., Zamorano, M., Rodríguez, M.I., Molero, E. \& Urrea, M.A. Implementation of the European Water Framework Directive: Integration of hydrological and regional planning at the Segura River Basin, southeast Spain. Land Use Policy, 28, pp. 242-256, 2011.

[6] United Nations Environment Programme (UNEP). One planet many people. Atlas of Our Changing Environment, 2005. Online. http://na.unep.net/atlas/

[7] Downward, S.R. \& Taylor, R. An assessment of Spain's Programa AGUA and its implications for sustainable water management in the province of Almería, southeast Spain. Journal of Environmental Management, 82, pp. 277-289, 2007.

[8] Directive 2000/60/EC of the European Parliament and of the Council of 23 October 2000 establishing a framework for Community action in the field of water policy.

[9] Confederación Hidrográfica del Segura (CHS). Esquema Provisional de Temas Importantes. Demarcación Hidrográfica del Segura, 2008. Online. http://www.chsegura.es/chs/planificacionydma/planificacion/index.html\#eti

[10] Agencia Andaluza del Agua. Consejería de Medio Ambiente. Proyecto de Plan Hidrológico de la Demarcación Hidrográfica de las Cuencas Mediterráneas Andaluzas, 2010. Online. http://www.juntadeandalucia.es/ medioambiente/site/web/menuitem.a5664a214f73c3df81d8899661525ea0/? 
vgnextoid=c00b8e2d2f5b8210VgnVCM1000001325e50aRCRD\&vgnextch annel=ee8feb3d87605210VgnVCM1000001325e50aRCRD

[11] Ministerio de Medio Ambiente. El agua en la economía española: Situación y perspectivas. Informe integrado del análisis económico de los usos del agua en España. Artículo 5 y Anejo III de la Directiva Marco de Agua, MIMAM: Madrid, 2007.

[12] Colino, J. (dir.), Estructura Económica de la Región de Murcia, Cívitas: Madrid, 1993.

[13] Lizárraga Mollinedo, C., Ortuño Padilla, A. \& Soler Domingo, D. La transformación socioeconómica de la cuenca del Segura. in Gómez, J.L., \& Grindlay, A.L. (dirs.). Agua, Ingeniería y Territorio: La Transformación de la Cuenca del río Segura por la Ingeniería Hidráulica. Confederación Hidrográfica del Segura: Murcia, pp. 357-434, 2008.

[14] Cortés García, F.J. Crecimiento económico y convergencia de la provincia de Almería. Boletín económico de ICE, 2839, pp. 11-25, 2005.

[15] Consejería de Agricultura y Agua de la Región de Murcia. Macromagnitudes del sector agrario, Dirección General de Industrias y Asociacionismo Agrario, 2005.

[16] Ministerio de Medio Ambiente, Rural y Marino (MARM). Estrategia nacional para la modernización sostenible de los regadíos horizonte 2015. Informe de Sostenibilidad Ambiental, Dirección General del Agua: Madrid, 2010. Online. http://www.mma.es/secciones/participacion_publica/ eval_amb/pdf/ISA_EAE_ENMSRH2015_210710_parte1.pdf

[17] Ministerio de Agricultura, Pesca y Älimentación. Plan Nacional de Regadíos, Horizonte 2008, Madrid, 2002.

[18] Karaboytcheva, M.K. Los efectos económicos de la inmigración: el sector de la agricultura en España. Documento de trabajo $\mathbf{n}^{\mathbf{0}} \mathbf{4}$, Real Instituto Elcano: Madrid, 2007. Online. http:/www.realinstitutoelcano.org/wps/ portal/rielcano/contenido?WCM_GLOBAL_CONTEXT=/elcano/elcano_es /zonas_es/demografia $+\mathrm{y}+$ poblacion/dt4-2007

[19] Colino, J. \& Martínez Paz, J.M. El agua en la agricultura del sureste español: Productividad, precio y demanda, in García Álvarez-Coque, J.M. (coord.), La agricultura mediterránea en el siglo XXI, Instituto Cajamar: Almería, pp. 199-221, 2002.

[20] Gozalo Mesa, J.D. La gestión del agua en una subregión semiárida: Importancia del agua como bien económico, desarrollo hidráulico y territorial en Almería ¿hacia un uso sostenible de los recursos hídricos?. Investigación para la obtención del Diploma de Estudios Avanzados. Programa de Doctorado en Urbanismo, Ordenación del Territorio y Medio Ambiente, Universidad de Granada. Tutor A.L. Grindlay, 2010. Online http://digibug.ugr.es/

[21] Oñate, J.J. Regadío y ecología: exigencias medio ambientales, in Gómez Limón, J.A., Calatrava, J., Garrido, A., Sáez, F. J. \& Xabadia, A. (eds.), La economía del agua de riego en España. Una perspectiva regional. Ed. Fundación Cajamar: El Ejido (Almería), pp. 407-428, 2009. Online. 
http://www.fundacioncajamar.es/publicacion-la-econom $\% \mathrm{C} 3 \% \mathrm{ADa}$-deagua-de-riego-en-espa\% $\% 3 \% \mathrm{~B} 1 \mathrm{a}$--una-perspectiva-regional-215.html

[22] Tolón, A. \& Lastra, X. La agricultura intensiva del poniente almeriense: Diagnóstico e instrumentos de gestión ambiental. $M+A$. Revista Electrónic@de Medio Ambiente, 8, pp. 18-40, 2010. Online http://revistas.ucm.es/ghi/18863329/articulos/MARE1010120018A.PDF

[23] Martínez-Fernández, J., Esteve-Selma, M.A. \& Calvo-Sendín, J.F. Environmental and Socioeconomic Interactions in the Evolution of Traditional Irrigated Lands: A Dynamic System Model. Human Ecology, 28, pp. 279-299, 2000.

[24] Gil, M., Garrido, A. \& Gómez-Ramos, A. Análisis de la productividad de la tierra y del agua en el regadío español, in Gómez Limón, J.A., Calatrava, J., Garrido, A., Sáez, F. J. \& Xabadia, A. (eds.), La economía del agua de riego en España. pp. 95-114, 2009.

[25] Ministerio de Medio Ambiente. Libro Blanco del Agua. Secretaría de Estado de Aguas y Costas, Madrid, 2000.

[26] Gómez Espín, J.M. La Modernización de regadíos en España (1973-2008). Proyectos y realidades, in Gómez Espín, J.M. \& Martínez Medina, R. (eds.), Desarrollo rural en el siglo XXI. Universidad de Murcia, pp. 57-102, 2009.

[27] Garrido, A. \& Llamas, M.R. Water Management in Spain: An Example of Changing Paradigms, in Dinar, A. \& Albiac, J. (eds.), Policy and Strategic Behaviour in Water Resource Management, Earthscan: London, pp. 125144, 2009.

[28] Lizárraga Mollinedo, C. \& Casas Jurado, A.C. Perspectivas de la política de desarrollo rural en la Unión Europea, 2007-2013, Economistas, 107, pp. 99104, 2006.

[29] Alcón, F., Arcas, N., de Miguel, M.D. \& Fernández-Zamudio, M.A. Adopción de tecnologías ahorradoras de agua en la agricultura, in Gómez Limón, J.A., Calatrava, J., Garrido, A., Sáez, F. J. \& Xabadia, A. (eds.), La economía del agua de riego en España. pp. 128-146, 2009.

[30] Albiac, J., Dinar, A. \& Sánchez-Soriano, J. (): "Game theory: A useful approach for policy evaluation in natural resources and the environment", in Dinar, A., Albiac, J. \& Sanchez-Soriano, J. (eds.), Game Theory and Policy Making in Natural Resources and the Environment, Routledge Explorations in Environmental Economics, Routledge: Abingdon, 2007.

[31] Varela Ortega, C. \& Hernández-Mora, N. Institutions and institutional reform in the Spanish water sector: a historical perspective, in Garrido, A. \& Llamas, M.R. (eds.) Water Policy in Spain. CRC Press: Boca Ratón USA, pp. 117-130, 2010.

[32] Menéndez Prieto, M. Facing the challenges of implementing the European Water Directive in Spain, in Garrido, A. \& Llamas, M.R. (eds.) Water Policy in Spain, CRC Press: Boca Ratón USA. pp. 175-184, 2010.

[33] Comunidad Autónoma de la Región de Murcia (CARM). Plan Estratégico de Desarrollo de la Región de Murcia 2007-2013: Murcia, 2006. 